\title{
Hydrochemistry and Quality Assessment of Water in Tannur Dam, Southern Jordan
}

\author{
Omar A. Al-Khashman, Hani M. Alnawafleh* \\ Faculty of Engineering, Al-Hussein Bin Talal University, Ma'an, Jordan \\ Email: *hanialnawafleh@ahu.edu.jo
}

How to cite this paper: Al-Khashman, O.A. and Alnawafleh, H.M. (2020) Hydrochemistry and Quality Assessment of Water in Tannur Dam, Southern Jordan. Open Journal of Modern Hydrology, 10, 1-19. https://doi.org/10.4236/ojmh.2020.101001

Received: December 3, 2019

Accepted: January 19, 2020

Published: January 22, 2020

Copyright $\odot 2020$ by author(s) and Scientific Research Publishing Inc. This work is licensed under the Creative Commons Attribution International License (CC BY 4.0).

http://creativecommons.org/licenses/by/4.0/ c) (i) Open Access

\begin{abstract}
The study was undertaken to assess the physicochemical and chemical quality of the Tannur dam water in southern Jordan. The water samples were collected in two intervals the first during May 2015 and the second during September 2015. All samples were analyzed for temperature, conductivity, dissolved oxygen, $\mathrm{pH}$, major cations $\left(\mathrm{Ca}^{2+}, \mathrm{Mg}^{2+}, \mathrm{K}^{+}, \mathrm{Na}^{+}\right)$, and major anions $\left(\mathrm{Cl}^{-}, \mathrm{NO}_{3}^{-}, \mathrm{HCO}_{3}^{-}\right.$and $\left.\mathrm{SO}_{4}^{2-}\right)$. The hydrogeochemical analyses of thirty-six water samples were used to determine the properties and type of water in the Tannur dam. The ion concentration in the water samples was from dissolution of carbonate rocks and ion exchange processes in clay. The general chemistry of water samples was typical alkaline earth waters with prevailing bicarbonate chloride. The PHREEQC Hydrogeochemical modeling was used to obtain the saturation indices of specific mineral phases, which might be related to interaction with water and aquifer, and to identify the chemical species of the dissolved ions. Calcite and dolomite solubility were assessed in terms of saturation index where they show positive values indication oversaturated SI $>0$. The hydrogeochemistry behavior is rather complicated and is affected by anthropogenic and natural sources. The positive correlation values between various parameters indicate that most of ions result from same lithological sources. The abundance of the major ions in water samples is in the following order: $\mathrm{HCO}_{3}^{-}>\mathrm{Ca}^{2+}>\mathrm{Cl}^{-}>\mathrm{NO}_{3}^{-}>\mathrm{SO}_{4}^{2-}>\mathrm{Na}^{+}>\mathrm{Mg}^{2+}>$ $\mathrm{K}^{+}$. Water samples of the Tannur dam are generally very hard, high to very high saline and medium alkaline in nature. High total hardness (TH) and total dissolved solids (TDS) in some samples identify the permissible for domestic and irrigation purposes. According to the residual sodium carbonate, SAR and conductivity values, the studied water is suitable for agricultural purposes.
\end{abstract}

\section{Keywords}

Hydrochemistry, Tannur Dam, Jordan, Saturation Indices, Water Quality 


\section{Introduction}

\subsection{Overview and Main Characteristics}

Jordan is considered among the poorest countries in the world in terms of water resources. The scarcity of water resources in Jordan imposes strategic difficulties for economic development especially for agriculture [1]. The demand on water resources is increasing with time for domestic and agricultural purposes. Jordan is characterized by semiarid climate, which suffers from water shortage and limited water supply. In recent years, water demand increased rapidly through the high rate of population growth and population influxes together with the higher needs for the industry in the Jordan [2]. Several studies were reported to date addressing the quality of water in Jordan. Salameh and Bannayan [3] studied the water quality in southern part of Jordan as a part of a comprehensive report about the water resources in Jordan. Salameh [4] studied the water quality degradation in several sites in Jordan. El Naqa and Al Kuisi [2] studied the hydrogeochemical modeling of the water seepages through Tannur dam in southern Jordan. Al-Khashman et al. [5] studied the environmental assessment of spring water in Tafila district, southern Jordan. Al-Tabbal and Al-Zboon [6] studied the suitability assessment of groundwater for irrigation and drinking purpose in the northern region of Jordan. Al-Khashman and Jaradat [7] studied the assessment of ground water quality and its suitability for drinking and agricultural uses in arid environment. Al-Khashman et al. [8] investigated the monitoring and assessment of spring water quality in southwestern basin of Jordan.

In order to meet such water needs, the Ministry of Water and Irrigation have selected number of sites in the southern area, that are suitable for construction of storage dams to be used primarily for domestic, recharge of groundwater and irrigation purposes. The Tannur dam (Figure 1) is one of these sites and the first roller compacted concrete (RCC) dam. The dam provides irrigation water to the southern Ghors irrigation scheme and industrial water for local area. Construction of the Tannur dam commenced in January 1998 and completion is expected on time in May 2001 (Figure 1). The dam is $60 \mathrm{~m}$ high, $250 \mathrm{~m}$ long and impounds 18 million $\mathrm{m}^{3}$ of runoff from Wadi Hasa, one of the major wadis discharging to the southern Dead Sea area. The elevation at the dam is approximately $400 \mathrm{~m}$ (Table 1). It forms of water supply and irrigation project serving 1200 ha of farmland and industrial demand in southern Jordan [2].

The Tannur dam location is in a steep valley of Wadi El-Hasa at Tannur mountain, approximately $5 \mathrm{~km}$ downstream from the bridge of King's highway, about $40 \mathrm{~km}$ south of Karak (Figure 2). The dam is located in a narrow V-shaped valley with abutment sides rising at about $30^{\circ}$ for up to $100 \mathrm{~m}$ above wadi. The rock foundation for half of dam height comprises interbedded limestone and marl, highly fractured in parts, and with the presence of gypsum seams and clay (weathered mudstone) layers.

The general characteristics of the dam are given in Table 1. Tannur dam is located in the southern Jordanian desert where the climate is arid, with rainfall 


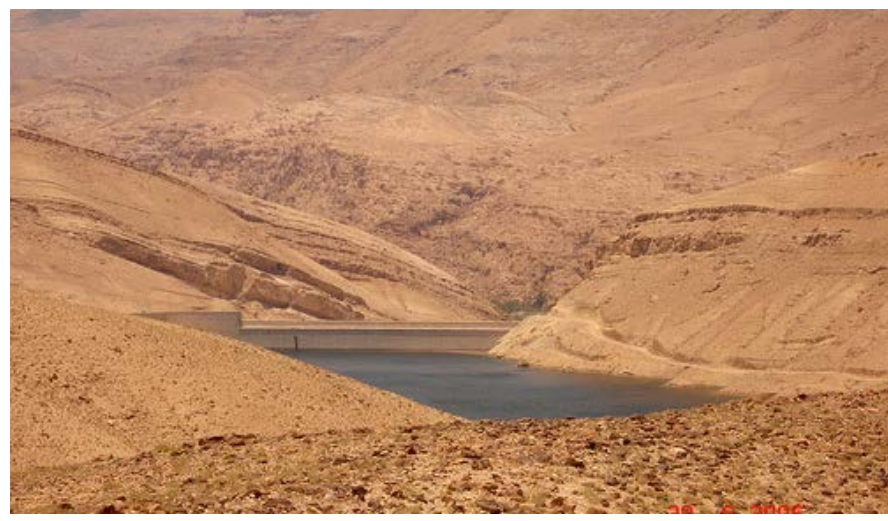

Figure 1. General view of the Tannur dam location.

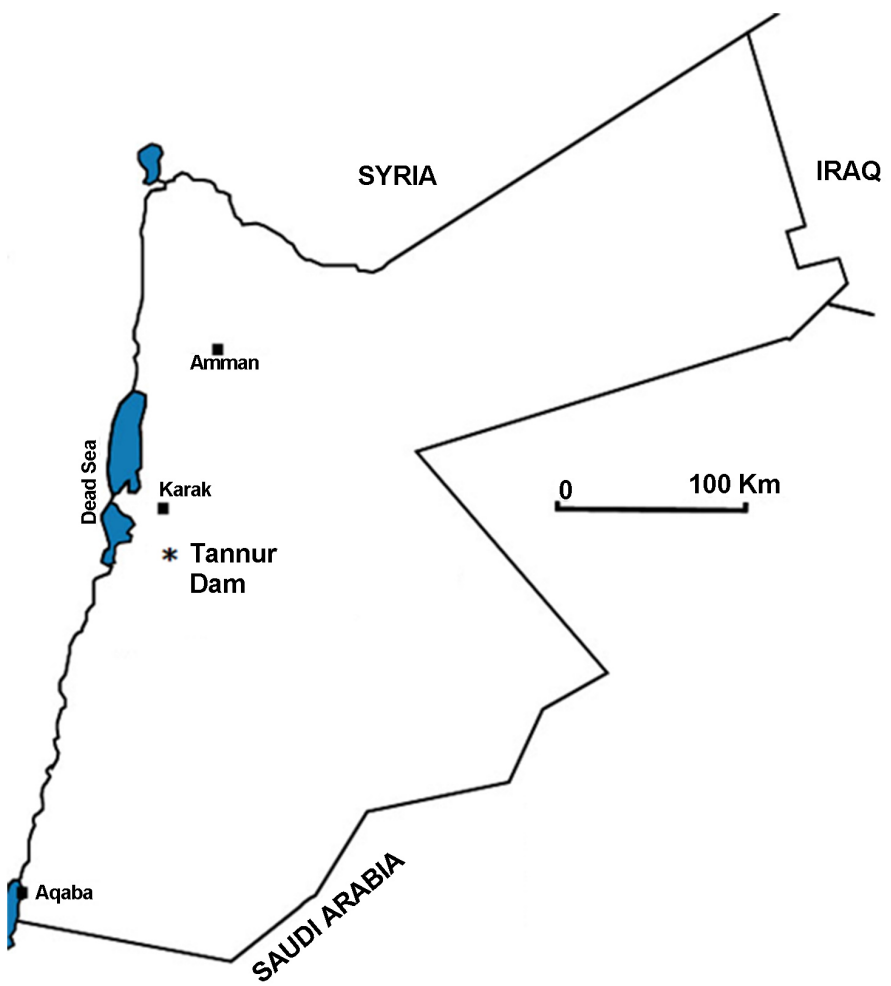

Figure 2. The Tannur dam location map.

Table 1. Characteristics of the Tannur dam.

\begin{tabular}{cc}
\hline Location & Wadi El-Hasa, Southern Jordan \\
\hline Height & $60 \mathrm{~m}$ \\
Length & $250 \mathrm{~m}$ \\
Width at crest & $12 \mathrm{~m}$ \\
Reservoir capacity & $17 \mathrm{MCM}$ \\
Annual yield & $8 \mathrm{MCM}$ \\
Roller Compacted Concrete (CRR) volume & $220,000 \mathrm{~m}^{3}$ \\
Purpose & Irrigation, water supply-flood control \\
Construction (starting and completion) year & $1999-2001$ \\
\hline
\end{tabular}


and runoff only occurring in the winter seasons (October to April). Annual rainfall is low, generally varied between $63-113 \mathrm{~mm} /$ year. The average temperature is $22.3^{\circ} \mathrm{C}$, with minimum values of $3.4^{\circ} \mathrm{C}$ in January and maximum of $35^{\circ} \mathrm{C}$ in July [9]. The maximum sunshine duration occurs in June with absolute values of 12.2 hours/day, but in winter (December and January) the average minimum sunshine is only about 4.2 hours/day. The average relative humidity varies from $40.9 \%$ to $26.2 \%$ in the winter months and from $22.7 \%$ to $36.4 \%$ in the summer season. The prevailing wind direction is from westerly to southwesterly. This paper examines the hydrochemical properties and quality of water in Tannur dam related to its suitability for agriculture and domestic use. Furthermore, a geochemical model was carried out using the computer software PHREEQC to explain the thermodynamic condition of water during water-rock interaction.

\subsection{Geology of the Study Area}

The geology of the study area is shown in Figure 3. The outcropping rocks at the dam location and reservoir area belong to the Ajlun group of Late Cretaceous [2] [10]. Fuheis-Hummar-Shueib (FHS) formations represent the oldest rocks found in the dam site area, representing the dam foundation rocks. These formations

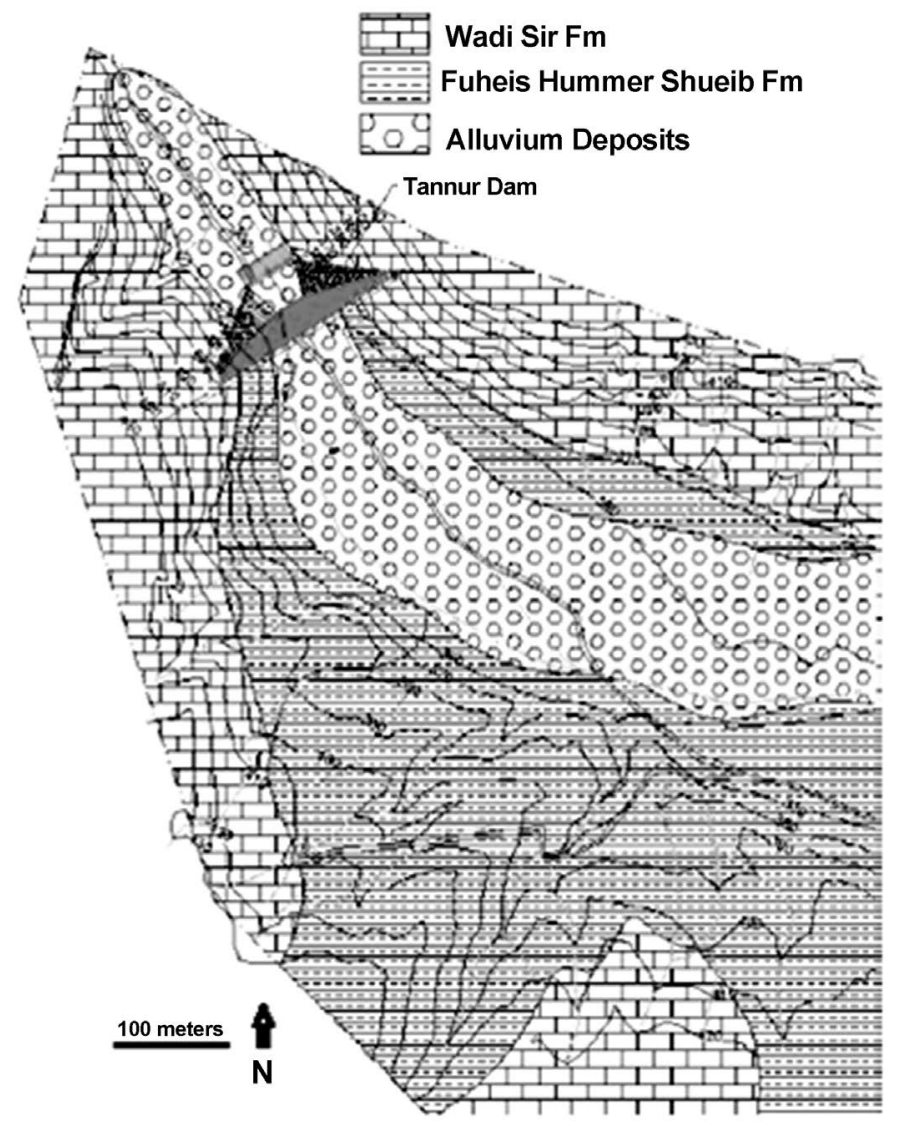

Figure 3. A simplified geological map of the Tannur dam area (slightly modified from El Naqa and Al Kuisi [2]). 
consist of thin to moderately thick bedded ( $5-55 \mathrm{~cm}$ thick) limestone, marlstone, marl and clayey marl with gypsum bands [11]. The limestone is moderately hard and moderately weak, and these strata contain small bands of marl and fossiliferous limestone up to $70 \mathrm{~cm}$ thick [10]. The Wadi As-Sir Limestone (WSL) formation (A7) is exposed over the whole of the study area. This formation is characterized by predominant hard buff dolomitic limestone, thickly and thinly bedded limestone with nodules of chert interbedded with marly limestone and dolomite wackstone [12]. The alluvium and wadi sediments comprise recent sub rounded to rounded, poorly sorted gravels ranging in size from pebbles to boulders. The clastic materials are composed of regional bedrock, mostly limestone, chert and sand grains [10] [12] [13] [14].

Structurally, the area is intensively faulted and folded as a result of various tectonic activities. The Wadi El Hasa fault is the major E-W faults in the study area. In the west it trends ENE and curves eastwards to the N-W and ESE direction. At the western side it branches into two faults. The Wadi El Has fault strikes generally E-W from the Dead Sea fault, which is about $25 \mathrm{~km}$ west of Tannur dam location [10] [12]. The minor faults at the eastern end of the Wadi El Hasa fault are considered to be dextral strike-slip faults as indicated by the peripheral small scale folding. Along the Wadi El Hasa fault, a volcanic plug has erupted.

\subsection{Hydrogeology}

The aquifer systems in the study area can be divided into three main aquifers; they are Kurnub Sandstone system (lower aquifer), middle aquifer systems (Wadi Es Sir Limestone aquifer) and shallow aquifer systems (upper aquifer).

\subsubsection{Kurnub Sandstone Aquifer}

The Kurnub aquifer consists of massive, white and varicolored sandstone reaching inn total thickness about [10] [15]. The Kurnub group composed primarily sandstone long the rift of the study area. The sequences jointed, well cemented to friable and highly permeable, hence possessing good aquifer properties [16]. The hydraulic parameters of this aquifer were derived from the pumping test data. The permeability of the aquifer is $4.5 \times 10^{-5} \mathrm{~m} / \mathrm{s}$ [17]. On the other hand, the storage coefficient and the transmissivity of the Kurnub aquifer were estimated to be 0.002 and $1.31 \times 10^{-3}$, respectively [2] [18].

\subsubsection{Ajlun and Belqa Group Aquifer System}

This aquifer system consists of Ajlun and Belqa group of the Upper Cretaceous sediments. There are only main aquifer systems (A4, A7, B2, and B4) out of twelve rock units in both groups [19]. Wadi Es Sir Formation (A7) is considered to be one of the most important groundwater reservoirs in the study area as well as in Jordan [20]. This formation consists of alternating marl, marly limestone, crystalline limestone, dolomitic limestone and chert nodules. It has an excellent potentiality of water bearing and has a permeability ranges between $2 \times 10^{-8}$ and 
$1.49 \times 10^{-5} \mathrm{~m} / \mathrm{s}$, with an average value of $5.5 \times 10^{-6} \mathrm{~m} / \mathrm{s}$ [17]. It is noticed that the permeability of middle aquifer (A7) is quite similar to that of lower aquifer (Kurnub Sandstone Aquifer).

\subsubsection{Alluvium Aquifer System}

This shallow aquifer system of Quaternary age extends along the wadi floor and consists of conglomerate, gravels and fragments of limestone, chert, basalts and sandstone of elevated terraces and old mantle rock. The total thickness of these water bearing sediments is estimated at $170 \mathrm{~m}$ [15]. The permeability of the aquifer ranges between $6.5 \times 10^{-4}$ and $1.3 \times 10^{-2} \mathrm{~m} / \mathrm{s}$, with an average value of 6.6 $\times 10^{-3} \mathrm{~m} / \mathrm{s}$ [17].

The majority of the aquifers in the study area are limestone, sandstone, dolomitic limestone and Silicified limestone. Secondary permeability is controlled by the structure and tectonic effects [21].

\section{Methodology}

\subsection{Sampling and Experimental Work}

Reservoir water samples were collected from thirty six locations in the dam, as shown in Figure 4.

The water samples were collected in two periods, the first during May 2015 and the second during September 2015. The collected water samples were stored in polyethylene bottles. The bottles were washed previously with deionized water and diluted hydrochloric acid. Before filling the bottle with the samples, the bottles were rinsed with the samples water and transported to a lab in cold storage.

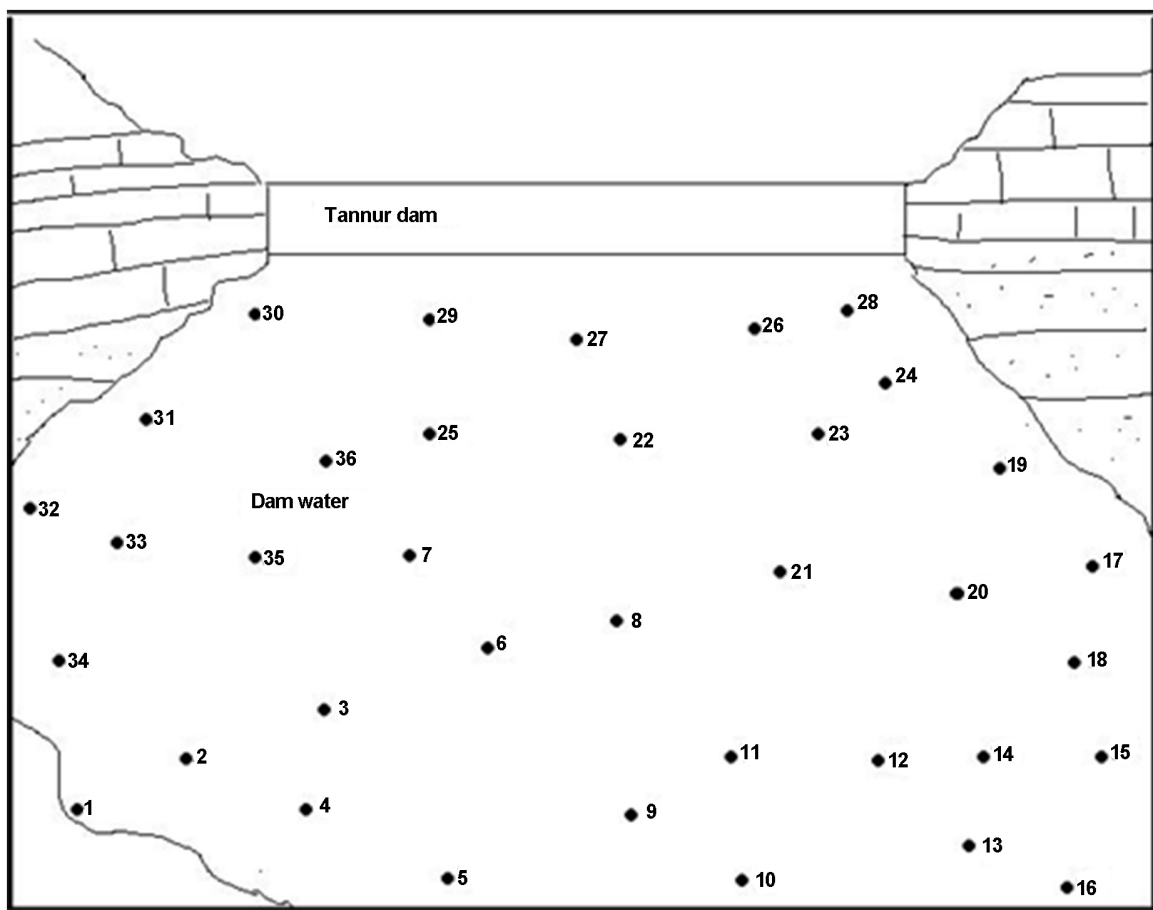

Figure 4. Location map of sampling sites. 
After collection the water samples were transferred from polyethylene containers $(1 \mathrm{~L})$ into polyethylene bottles $(250 \mathrm{~mL})$, and then filtered through a $45-\mu \mathrm{m}$ cellulose nitrate membrane filter using a vacuum pump in order to remove insoluble particles. Each sample was divided into two polyethylene bottles one for major anion analyses and the other was acidified the samples to $\mathrm{pH}<2$ for cation analysis and all samples were kept in refrigerator at $4^{\circ} \mathrm{C}$ until the time of chemical analysis, which was usually performed within one week after bottling. Electrical conductivity, $\mathrm{pH}$, temperature and dissolved oxygen (DO) of the water samples were measured on site by using portable $\mathrm{pH}$ meter, EC meter, dissolved oxygen meter and temperature meter. All glassware and polyethylene bottles were soaked in $20 \% \mathrm{HNO}_{3}$ for 1 day and rinsed several times with deionized water before use. Conductivity measurements were carried out with 470 JENWAY conductivity meter with temperature compensation, while the $\mathrm{pH}$ values were measured in the field using 370 JENWAY $\mathrm{pH}$-meters equipped with a combination glass electrode. Calibration was always carried out before measurement using standards buffer solutions of $\mathrm{pH} 4.00$ and 7.00. Dissolved oxygen values were measured in the field using field DO-meter (WTW equipment). TDS was measured by the conductivity measurements. The calculation is carried out by the following equation: TDS $(\mathrm{mg} / \mathrm{l})=\mathrm{EC}(\mu \mathrm{s} / \mathrm{cm}) \times 0.64$, where $\mathrm{EC}$ is the electrical conductivity (Howari et al., 2005). The bicarbonate concentration was determined by titration of the water samples with $0.02 \mathrm{H}_{2} \mathrm{SO}_{4}$ using methyl orange as indicator. Major anions $\left(\mathrm{Cl}^{-}, \mathrm{NO}_{3}^{-}\right.$and $\left.\mathrm{SO}_{4}^{2-}\right)$ were analyzed by 100 Dionex Ion Chromatography instruments equipped with AG4A-SC guard column, AS4ASC separating column, SSR1 anion self-regeneration suppresser and conductivity detector. The samples were injected through $25 \mathrm{MI}$ sample loop and eluted at $2.0 \mathrm{ml}$ min-I using $1.7 \mathrm{~m} \mu \mathrm{NaHCO}_{3}$ and $1.8 \mathrm{~m} \mu \mathrm{Na}_{2} \mathrm{CO}_{3}$. The system was calibrated with a certified standard from Dionex. Major cations $\left(\mathrm{Ca}^{2+}, \mathrm{Mg}^{2+}\right.$, $\mathrm{Na}^{+}$, and $\mathrm{K}^{+}$) were measured by 800 Varian flames Atomic Absorption Spectrophotometer. The concentrations of cations were determined using a CS12 analytical column, CG 12 guard column, using $20 \mathrm{~m} \mu \quad \mathrm{CH}_{4} \mathrm{SO}_{3}^{-}$. The concentration of bicarbonate was determined by titration with 0.01 hydrochloric acid using methyl orange as indicator. The standard solutions of the anions and cations as well as blank samples were prepared with different concentrations. All standard solution were made daily by diluting the stock solutions with $0.01 \mathrm{M} \mathrm{HNO}_{3}$ [22], which was prepared from analytical grade $\mathrm{HNO}_{3}$ solution obtained from Merck. A quality control procedure, including, recalibration of the instruments, analysis of triplicate samples and recovery test of standard reference material was used to control data quality [23]. All chemicals and reagents used in this study were of analytical grade unless otherwise stated. Deionized water (Milli-Q $18.2 \mu \mathrm{s} / \mathrm{cm}$ ) was used for all dilutions. Standard solution was prepared by diluting the stock solutions.

To prevent the sample contamination with any source of pollution, all the glassware, Pyrex and plastic containers were washed several times with soap, deionized water and treated with $0.01 \mathrm{M} \mathrm{HNO}_{3}$ and finally rinsed with ul- 
tra-pure water. After analysis the accuracy of these standards were within $\pm 7 \%$. The numerical simulation model PHREEQ was used to set up the hydrological components of the groundwater, especially the saturation indices of minerals (calcite, dolomite, gypsum, anhydrate and halite) to test the saturation of minerals.

\subsection{Hydrochemical Evaluation and Water Quality Indices}

To assess water quality and hydrochemistry of water samples, the parameters such as; Total Hardness $\left(\mathrm{TH}_{\mathrm{mg} / \mathrm{L}}\right)$, Sodium Adsorption Ratio (SAR), Percent Sodium (Na\%), Residual Sodium Carbonate (RSC) and Permeability Index (PI) were calculated based on the chemical characteristics of water samples beside the hydrochemical parameters which include hydrochemical evaluation and Saturation Index (SI). These parameters and assessment indices will be defined later.

\section{Results and Discussion}

\subsection{Chemical Characteristics of Water}

Thirty six water samples were collected from reservoir water in Tannur dam during the studying period, May 2015 and September 2015. Statistical summary of volume-weighted mean concentrations of physical and chemical parameters are presented in Table 2.

The ratio of total anions to that of cations (( anions $) /\left(\sum\right.$ cations $\left.)\right)$ was an indicator for the completeness of measured parameters [24]. The average equivalent sum of cations to that of anions $\left(\left(\sum\right.\right.$ anions $) /\left(\sum\right.$ cations $\left.)\right)$ was $0.89 \pm 0.32$. Also, for the set of samples considered in this study, linear regression of cation sum on anion sum gave value $\mathrm{R}^{2}=0.93$ indicating that the quality of the data was good. The in-situ measured temperature for the water samples in the wet season (May 2015) ranged between $9.0^{\circ} \mathrm{C}$ and $12.8^{\circ} \mathrm{C}$, with an average value of $10.6^{\circ} \mathrm{C}$. On the other hand, the temperature of water samples in the dry season (September 2015) varied between $11.0^{\circ} \mathrm{C}$ and $18.1^{\circ} \mathrm{C}$, with an average value of $13.8^{\circ} \mathrm{C}$. Dissolved oxygen (DO) in water samples in wet season ranged from 3.4 and 6.6 $\mathrm{mg} / \mathrm{l}$, with an average value of $5.8 \mathrm{mg} / \mathrm{l}$, but in dry season ranged from $4.1 \mathrm{mg} / \mathrm{l}$ to $6.9 \mathrm{mg} / \mathrm{l}$, with an average value $5.41 \mathrm{mg} / \mathrm{l}$. The water samples of the study area have $\mathrm{pH}$ values varied from 6.8 to 8.2 (alkaline type) with an average values in wet and dry seasons 7.6 and 7.9, respectively. The high value of $\mathrm{pH}$ content has resulted from the increase of calcite from carbonate rocks in the study area. In the water samples, the EC in wet season ranged between 1210 and $1910 \mu \mathrm{s} / \mathrm{cm}$, with a mean value of $1501 \mu \mathrm{s} / \mathrm{cm}$, while, in the dry season EC varied from 1800 and $1968 \mu \mathrm{s} / \mathrm{cm}$, with a mean value of $1903 \mu \mathrm{s} / \mathrm{cm}$. However, the high conductivity of the water samples in Shoubak basin corresponding to the highest of dominant ions, which is result by ion exchange and solubility of rocks in aquifer [22] [25]. TDS values in water varied from $772 \mathrm{mg} / \mathrm{l}$ to $1241 \mathrm{mg} / \mathrm{l}$ in wet season, with a mean value of $942 \mathrm{mg} / \mathrm{l}$ but in dry season it ranged from $1155 \mathrm{mg} / \mathrm{l}$ to 1264 $\mathrm{mg} / \mathrm{l}$, with a mean value of 1218 (Table 2). The increase of salinity in water 
Table 2. Summary of chemical analysis of water samples in Tannur dam.

\begin{tabular}{ccccccccc}
\hline & \multicolumn{3}{c}{ Wet season (May, 2015) } & \multicolumn{3}{c}{ Dry season (September, 2015) } \\
\hline Parameters & Min & Max & Mean & St.dev & Min & Max & Mean & St.dev \\
\hline $\mathrm{T}\left({ }^{\circ} \mathrm{C}\right)$ & 9.0 & 13.1 & 10.5 & 0.41 & 11.0 & 18.1 & 13.8 & 0.32 \\
$\mathrm{pH}$ & 6.8 & 8.2 & 7.6 & 0.26 & 7.1 & 8.2 & 7.9 & 0.19 \\
$\mathrm{EC}(\mu \mathrm{s} / \mathrm{cm})$ & 1210 & 1910 & 1501 & 180.0 & 1800 & 1968 & 1903 & 37.1 \\
$\mathrm{DO}(\mathrm{mg} / \mathrm{l})$ & 3.4 & 6.6 & 5.8 & 0.18 & 4.0 & 6.9 & 5.4 & 0.11 \\
$\mathrm{Ca}^{2+}(\mathrm{mg} / \mathrm{l})$ & 102.1 & 150.3 & 126.3 & 0.6 & 150.6 & 182.3 & 166.3 & 0.2 \\
$\mathrm{Mg}^{2+}(\mathrm{mg} / \mathrm{l})$ & 43.6 & 71.4 & 54.8 & 0.6 & 66.9 & 79.6 & 73.9 & 0.3 \\
$\mathrm{Na}^{+}(\mathrm{mg} / \mathrm{l})$ & 71.3 & 135.7 & 92.1 & 0.8 & 103.2 & 135.7 & 131.1 & 0.4 \\
$\mathrm{~K}^{+}(\mathrm{mg} / \mathrm{l})$ & 15.7 & 35.2 & 23.5 & 0.1 & 36.2 & 47.3 & 43.1 & 0.1 \\
$\mathrm{HCO}_{3}^{-}(\mathrm{mg} / \mathrm{l})$ & 262.3 & 475.8 & 341.6 & 1.1 & 451.4 & 481.9 & 475.8 & 0.17 \\
$\mathrm{Cl}^{-}(\mathrm{mg} / \mathrm{l})$ & 50.2 & 195.3 & 163.5 & 0.4 & 184.6 & 215.6 & 209.2 & 0.20 \\
$\mathrm{NO}_{3}^{-}(\mathrm{mg} / \mathrm{l})$ & 130.2 & 198.4 & 161.5 & 0.3 & 179.8 & 243.6 & 223.3 & 0.23 \\
$\mathrm{SO}_{4}^{2-}(\mathrm{mg} / \mathrm{l})$ & 91.2 & 187.2 & 110.4 & 0.6 & 188.6 & 154.8 & 191.5 & 0.21 \\
$\mathrm{TDS}_{(\mathrm{mg} / \mathrm{l})}$ & 772 & 1241 & 942 & 136.2 & 1155 & 1264 & 1218 & 34.21 \\
\hline & & & & & & & & \\
\hline
\end{tabular}

samples can be explained by the chemical reactions that take place during water-rock interaction and through long period of contact with rocks. Dissolved Oxygen (DO) varied in the range from $3.4 \mathrm{mg} / \mathrm{l}$ to $6.6 \mathrm{mg} / \mathrm{l}$ in the wet season, with a mean value of $5.8 \mathrm{mg} / \mathrm{l}$, but in dry season it ranged from $4.0 \mathrm{mg} / \mathrm{l}$ to 6.9 $\mathrm{mg} / \mathrm{l}$, with a mean value of 5.4. The chemical composition of the water in Tannur dam was variable. The chemical parameters including statistical measures were shows in Table 2. The abundance of the major ions in water samples is in the following order: $\mathrm{HCO}_{3}^{-}>\mathrm{Ca}^{2+}>\mathrm{Cl}^{-}>\mathrm{NO}_{3}^{-}>\mathrm{SO}_{4}^{2-}>\mathrm{Na}^{+}>\mathrm{Mg}^{2+}>\mathrm{K}^{+}$. The concentration of calcium ion in wet season ranged from $102.1 \mathrm{mg} / \mathrm{l}$ to 150.3 $\mathrm{mg} / \mathrm{l}$, with a mean value of $126.3 \mathrm{mg} / \mathrm{l}$ but in dry season varied from $150.6 \mathrm{mg} / \mathrm{l}$ and $182.3 \mathrm{mg} / \mathrm{l}$, with a mean value of $166.3 \mathrm{mg} / \mathrm{l}$. Higher value of calcium in the wet season was due to release of calcium from the sedimentary carbonate rocks and soils to the aquifer (Al-Khashman, 2006). Calcium often comes from carbonate minerals such as calcite and dolomite, which commonly occurs in sedimentary and volcanic rocks, surrounded the study area. In wet season the concentration of $\mathrm{Mg}^{2+}$ in water ranged from $43.6 \mathrm{mg} / \mathrm{l}$ and $71.4 \mathrm{mg} / \mathrm{l}$ with a mean value of $54.8 \mathrm{mg} / \mathrm{l}$ but in dry season the concentration of $\mathrm{Mg}^{2+}$ varied from 66.9 to $79.6 \mathrm{mg} / \mathrm{l}$, with a mean value of $73.9 \mathrm{mg} / \mathrm{l}$. The maximum content of $\mathrm{Mg}^{2+} \mathrm{ex}-$ ists on the eastern side of the study area is related to the dissolution of volcanic rock which is present in this area and from chemical fertilizers [26]. The source of $\mathrm{Ca}^{2+}$ and $\mathrm{Mg}^{2+}$ in the water dam is believed to be limestone, dolomite, gypsum and anhydrite in the Wadi Es Sir and FHS formations [2]. The presence of $\mathrm{HCO}_{3}^{-}$in the water samples is derived from carbon dioxide in the atmosphere, soils and by dissolution of carbonate rocks. The increasing of bicarbonate in the 
dry season is attributed to the dissolution of carbonate rock in the study area (Figure 5). Sodium is the most abundant cation in the hydrosphere and present in natural water. The common source of sodium in the water samples is gypsum in sedimentary rocks, weathering of plagioclase and feldspar, which are typical constituents of volcanic rock surround the study area and evaporate deposits. Nitrate in water generally originates from several natural and human sources on the earth surface [27]. Also, nitrogen value in groundwater is derived from the biosphere [28]. The nitrate content in the water of Tannur dam in wet season ranged from $130.2 \mathrm{mg} / \mathrm{l}$ to $198.4 \mathrm{mg} / \mathrm{l}$ with a mean value of $161.5 \mathrm{mg} / \mathrm{l}$, whereas, the nitrate in dry season varied from $179.8 \mathrm{mg} / \mathrm{l}$ to $243.6 \mathrm{mg} / \mathrm{l}$ with a mean value of $223.3 \mathrm{mg} / \mathrm{l}$. The main source of nitrate in the water samples is related to the intensive use of nitrogen fertilizers in the nearby agricultural lands in the eastern and northern side of the Tannur dam, where most of the farms are located and manure and plant decomposition [1] [29].

\subsection{Hydrochemical Evaluation of the Water Samples}

Human activities near the Tannur dam site have had direct and indirect effects on the rate of water contamination. The direct effects on water include dissolution and transport of excess quantities of fertilizers with associated materials and hydrological alteration related to agriculture activities. While, the indirect effects include changes in water-rock reactions in soils and aquifers caused by increased concentration of major ions [30] [31]. Groundwater chemistry exchange matter with the various minerals and gases within the aquifer which it resulting from dissolution and precipitation of minerals [32]. Saturation indices of minerals in the water samples can be expressed by the saturation index (SI). The SI is defined as the logarithm of the ratio of the ion activity product of the mineral equilibrium constant at a given temperature [33]. When SI $<1$ the water is undersaturated and the minerals will dissolve. If the ratio of saturated indices greater than 1; the water is supersaturated and the minerals tend to be precipitated [32] [33]. On the other hand, if SI is equal to 1, the water is in equilibrium with the

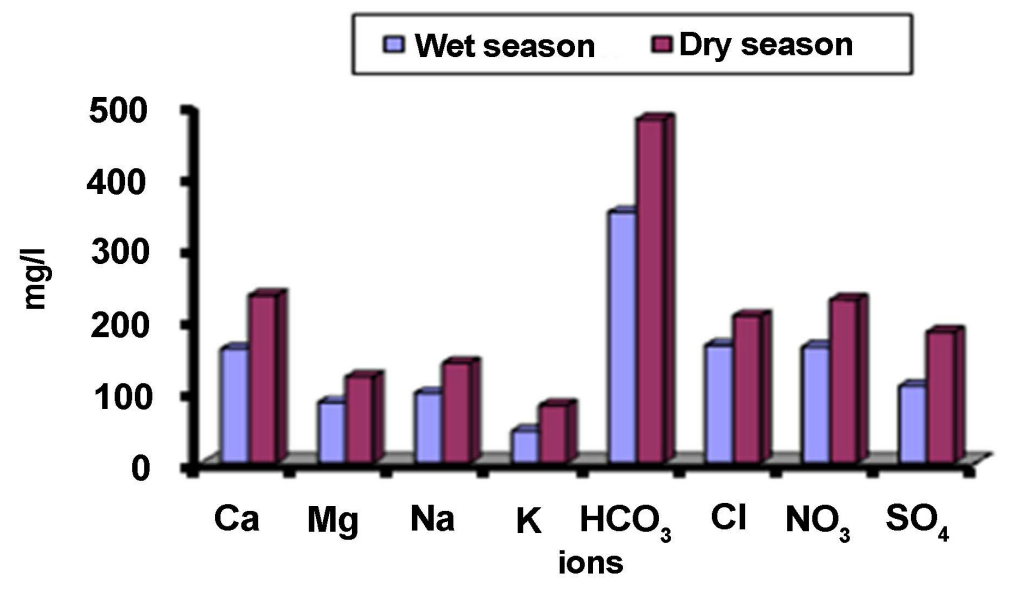

Figure 5. Mean concentration of ions in water samples. 
mineral. The statistical of saturation indices of water samples were presented in (Table 3). All water samples have positive calcite and dolomite indices; indicate that the water was oversaturated with respect to calcite and dolomite. On the other hand, all the water samples indicate negative value for gypsum, halite and anhydrate indices; which means that all of the water samples below the saturation state with respect to the gypsum and anhydrate and they are able to dissolve additional amount of these minerals. The saturation indices at different water sampling locations in the study area were plotted in Figure 6. It is noticed that the water samples are oversaturated with respect to calcite and dolomite, slightly under saturated with respect to anhydrate and gypsum, but highly under saturated with respect to halite.

The geochemical evolution of water samples can be understood by plotting the concentrations of major ions on the trilinear diagram of Piper [34] (Figure 7) to determine the water type according to the Langguth classification [35]. Figure 7 shows that most of water samples analyzed during May 2015 and September 2015 in the field of mixed $\mathrm{Ca}^{2+}-\mathrm{Mg}^{2+}-\mathrm{Cl}^{-}$type of water, whereas some samples are representing $\mathrm{Ca}^{2+}-\mathrm{Cl}^{-}$and $\mathrm{Na}^{+}-\mathrm{Cl}^{-}$types. From the Figure, alkaline earths $\left(\mathrm{HCO}_{3}^{-}, \mathrm{Ca}^{2+}\right.$ and $\left.\mathrm{Mg}^{2+}\right)$ significantly exceed the alkalis $\left(\mathrm{Na}^{+}\right.$and $\left.\mathrm{K}^{+}\right)$and strong acids chloride and sulfate. Water chemistry originates from dissolution of carbonate rocks. However, the water was generally classified as $\mathrm{Ca}-\mathrm{HCO}_{3}$ water with low salinity. The hardness of water samples was classified according to Sawyer and McCarty [36]. The hardness of water resulted from the presence of calcium, magnesium, bicarbonate and sulfate concentrations that are the most abundant ions. (Table 4) shows the classification of the water samples based on their hardness. The calculated of hardness of the water samples as $\mathrm{CaCO}_{3}$ in $\mathrm{mg} / \mathrm{L}$ according to Todd [27]:

$$
\mathrm{TH}=2.5 \mathrm{Ca}^{2+}+4.1 \mathrm{Mg}^{2+}
$$

It was clearly shown from Table 4 that the water samples in wet season can be classified as hard water, 29 water samples show relatively very hard water. However, in the dry season two water samples are classified as hard water while the most of water samples were considered as very hard water. The general increase of water hardness from wet to dry season can be attributed to the dissolution of carbonate rocks that also includes traces of evaporate deposits and percolation of rainwater to the saturation zone [20].

Table 3. Statistical analyses of saturation indices of water samples.

\begin{tabular}{ccccccccc}
\hline & \multicolumn{3}{c}{ Wet Season (May 2015) } & \multicolumn{4}{c}{ Dry Season (September 2015) } \\
\hline Para & Min & Max & Mean & St.dev & Min & Max & Mean & St.dev \\
\hline $\mathrm{SI}_{\text {calcite }}$ & 0.07 & 1.03 & 0.32 & 0.37 & 0.53 & 1.06 & 0.87 & 0.13 \\
$\mathrm{SI}_{\text {dolomite }}$ & 0.66 & 1.93 & 1.33 & 0.41 & 0.79 & 1.84 & 1.16 & 0.22 \\
$\mathrm{SI}_{\text {anhydrate }}$ & -1.61 & -0.45 & -1.03 & 0.32 & -1.06 & -0.39 & -0.80 & 0.20 \\
$\mathrm{SI}_{\text {gypsum }}$ & -1.69 & -0.83 & -1.29 & 0.26 & -1.69 & -0.75 & -1.10 & 0.15 \\
$\mathrm{SI}_{\text {halite }}$ & -7.92 & -4.32 & -5.78 & 1.14 & -8.92 & -4.09 & -6.32 & 0.62 \\
\hline
\end{tabular}




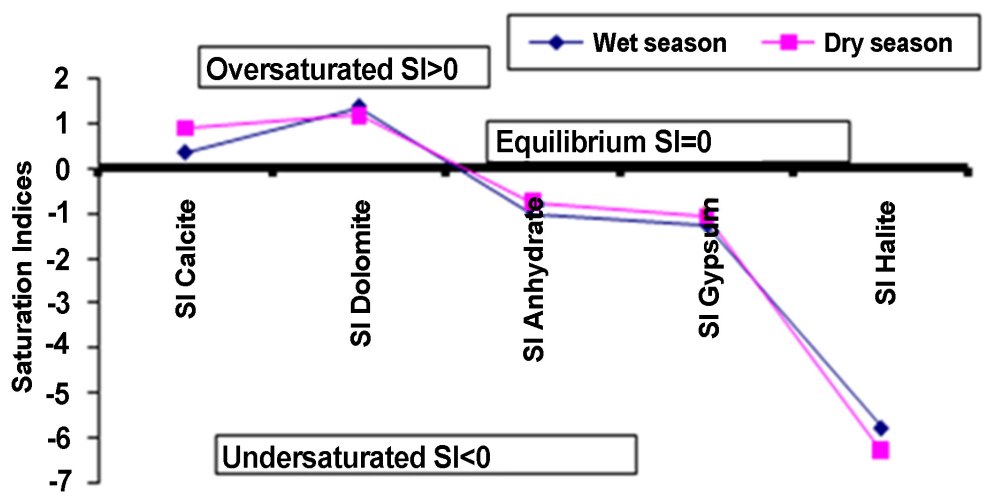

Figure 6. Saturation indices of minerals in water samples.

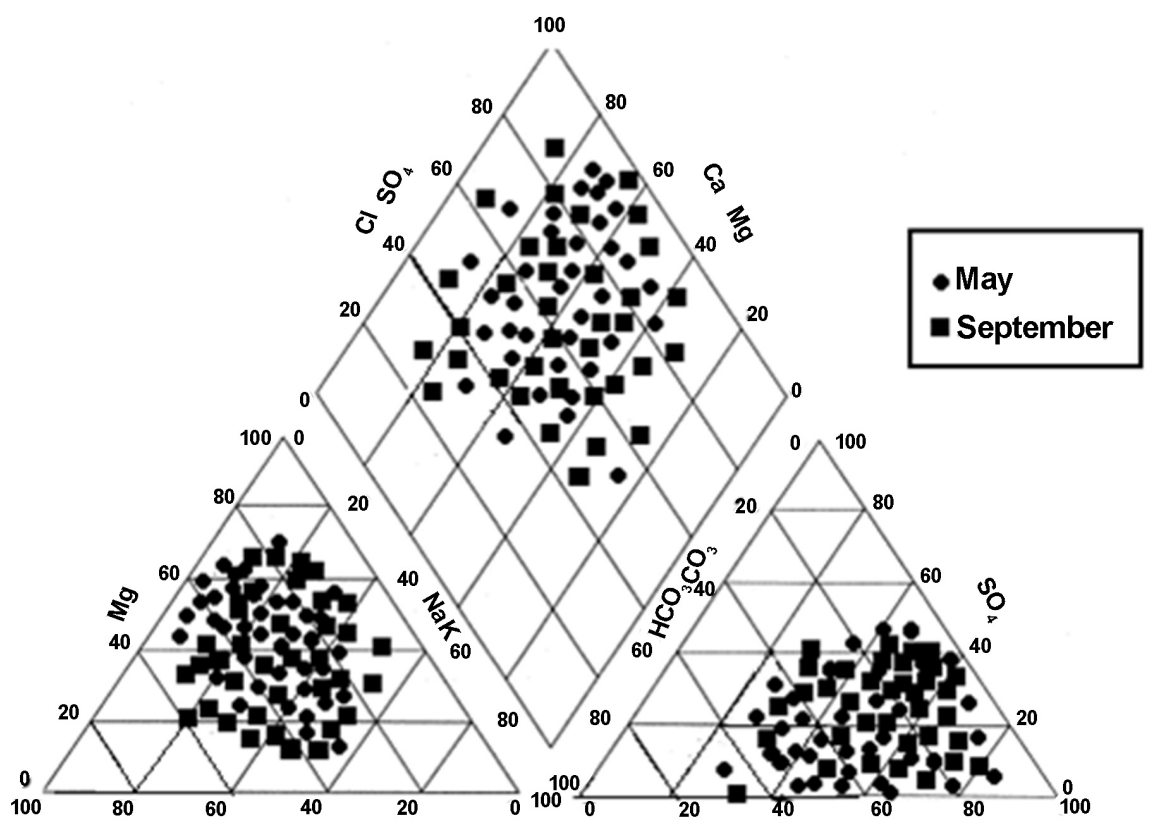

Figure 7. Piper diagram of water samples in Tannur dam.

Table 4. Classification of the water samples on the basis of the total hardness.

\begin{tabular}{cccccc}
\hline & & \multicolumn{2}{c}{ Wet season } & \multicolumn{2}{c}{ Dry season } \\
\hline Total hardness (mg/l) & Water class & No. of samples & Samples \% & No. of samples & Samples \% \\
\hline $0-75$ & Soft & - & - & - & - \\
$75-150$ & Moderate & - & - & - & - \\
$150-300$ & Hard & 7 & 19.4 & 2 & 5.6 \\
$>300$ & Very hard & 29 & 80.6 & 34 & 94.4 \\
\hline
\end{tabular}

\subsection{Hydrochemical Coefficient}

The ratio of $\mathrm{Ca}^{2+} / \mathrm{Mg}^{2+}, \mathrm{Na}^{+} / \mathrm{Cl}^{-}, \mathrm{Mg}^{2+} / \mathrm{Ca}^{2+}+\mathrm{Mg}^{2+}, \mathrm{SO}_{4}^{2-} / \mathrm{Cl}^{-}$and $\mathrm{Ca}^{2+} / \mathrm{Na}^{+}$ were calculated for water samples (Table 5). In the water samples, $\mathrm{Ca}^{2+} / \mathrm{Mg}^{2+}$ equivalent ratios were $>1.0$, the $\mathrm{Ca}^{2+} / \mathrm{Mg}^{2+}$ was higher in water samples due to higher carbonate concentration in the water. High correlation was found between 
Table 5. Hydrochemical coefficient of water samples.

\begin{tabular}{ccccccccc}
\hline & \multicolumn{3}{c}{ Wet season (May 2015) } & \multicolumn{4}{c}{ Dry season (September 2015) } \\
\hline Ionic ratio & Min & Max & Mean & St.dev & Min & Max & Mean & St.dev \\
$\mathrm{Ca} / \mathrm{Mg}$ & 1.23 & 1.60 & 1.41 & 0.10 & 1.20 & 1.66 & 1.33 & 0.12 \\
$\mathrm{Na} / \mathrm{Cl}$ & 0.58 & 1.11 & 0.85 & 0.14 & 0.82 & 1.25 & 1.10 & 0.10 \\
$\mathrm{Mg} / \mathrm{Ca}+\mathrm{Mg}$ & 0.35 & 0.65 & 0.44 & 0.09 & 0.35 & 0.76 & 0.52 & 0.09 \\
$\mathrm{SO} / \mathrm{Cl}$ & 0.40 & 0.82 & 0.62 & 0.12 & 0.45 & 0.86 & 0.66 & 0.08 \\
$\mathrm{Ca} / \mathrm{Na}$ & 1.15 & 1.76 & 1.48 & 0.14 & 1.22 & 1.82 & 1.52 & 0.18 \\
\hline
\end{tabular}

calcium and magnesium of water $\left(R^{2}=0.81\right)$, suggesting that the common source of these ions from carbonate dissolution in the water. While the median $\mathrm{Na}^{+} / \mathrm{Cl}^{-}$equivalent ratios were $<1$, the lower ratio of $\mathrm{Na}^{+} / \mathrm{Cl}^{-}$in water can due to dissolution with clay minerals exchanging $\mathrm{Na}^{+}$for $\mathrm{Ca}^{2+}$. On the other hand, strong correlation was found between sodium and chloride of water $\left(\mathrm{R}^{2}=0.91\right)$ (Table 6), suggesting that the common source of these ions from salt dissolution. The possible sources of these ions were anthropogenic sources and natural sources. The median $\mathrm{Mg}^{2+} / \mathrm{Ca}^{2+}+\mathrm{Mg}^{2+}$ ratios were $<1$ indicating weathering of limestone and dolomite, while the median $\mathrm{Ca}^{2+} / \mathrm{Na}^{+}$equivalent ratios in two periods varied between 1.48 to 1.82 , this ratio is high in water as a result of solubility of carbonate in the study area. The median $\mathrm{SO}_{4}^{2-} / \mathrm{Cl}^{-}$ratios were $<1$ indicating the dissolution of gypsum and limestone in the water. Chloride ion is highly correlated with sodium $\left(\mathrm{R}^{2}=0.91\right)$, while they are better correlated with $\mathrm{HCO}_{3}^{-}, \mathrm{SO}_{4}^{2-}$ and $\mathrm{Mg}^{2+}\left(\mathrm{R}^{2}=0.74,0.72\right.$ and 0.68$)$ respectively.

\subsection{Irrigation Water Quality}

The suitability of water for irrigation is dependent on the effects of its mineral constituents on both plants and the soil [27] [37]. The quality of water for irrigation water is based on the total salt concentration of the water, the concentration of specific ions that may be toxic to plants. Sodium adsorption ratio (SAR) is an important parameter for determining the suitability of water for irrigation because it is a measure of alkali and sodium hazard to plant [38]. The sodium adsorption ratio (SAR) is defined as follows where the concentrations of the constituents are expressed in milliequivalent per liter (meq/l).

$$
\mathrm{SAR}=\mathrm{Na} /\{\operatorname{sqrt}(\mathrm{Ca}+\mathrm{Mg}) / 2\}
$$

The $S A R$ values ranged from 1.48 to 2.29 with a mean value of 1.75 during the wet season (May 2015) and 2.08 to 2.44 with a mean value of 2.20 during dry season (September 2015). The dam water of Tannur was classified with respect to SAR (Richards, 1954). All analytical data plotted on the US salinity diagram [39] shows that most of water samples classified in the field of C3S1, indicating high salinity with low sodium water. This type of water is suitable for irrigation on almost all types of soil (Figure 8). Another parameter can be used for classification of irrigation water is the sodium percentage while, sodium reacts with 
Table 6. Correlation matrix for different water quality parameters, cells show the Pearson correlation coefficient and the corresponding $P$-value.

\begin{tabular}{cccccccc}
\hline & $\mathrm{Ca}$ & $\mathrm{Mg}$ & $\mathrm{Na}$ & $\mathrm{K}$ & $\mathrm{HCO}_{3}$ & $\mathrm{Cl}$ & $\mathrm{NO}_{3}$ \\
\hline $\mathrm{Ca}$ & & & & & & & \\
$\mathrm{Mg}$ & 0.811 & & & & & & \\
$\mathrm{Na}$ & 0.000 & & & & & & \\
& 0.401 & 0.310 & & & & & \\
$\mathrm{~K}$ & 0.000 & 0.000 & & & & & \\
& 0.661 & 0.351 & 0.132 & & & & \\
$\mathrm{HCO}_{3}$ & 0.000 & 0.000 & 0.000 & & & & \\
& 0.681 & 0.462 & 0.021 & 0.521 & & & \\
$\mathrm{Cl}$ & 0.742 & 0.000 & 0.000 & 0.001 & 0.000 & & \\
& 0.000 & 0.000 & 0.000 & 0.001 & 0.000 & & \\
$\mathrm{NO}_{3}$ & 0.341 & 0.470 & 0.521 & 0.426 & 0.463 & 0.331 & \\
& 0.001 & 0.001 & 0.000 & 0.000 & 0.000 & 0.000 & \\
$\mathrm{SO}_{4}$ & 0.640 & 0.720 & 0.701 & 0.601 & 0.592 & 0.741 & 0.294 \\
& 0.000 & 0.000 & 0.000 & 0.000 & 0.001 & 0.002 & 0.001 \\
\hline
\end{tabular}

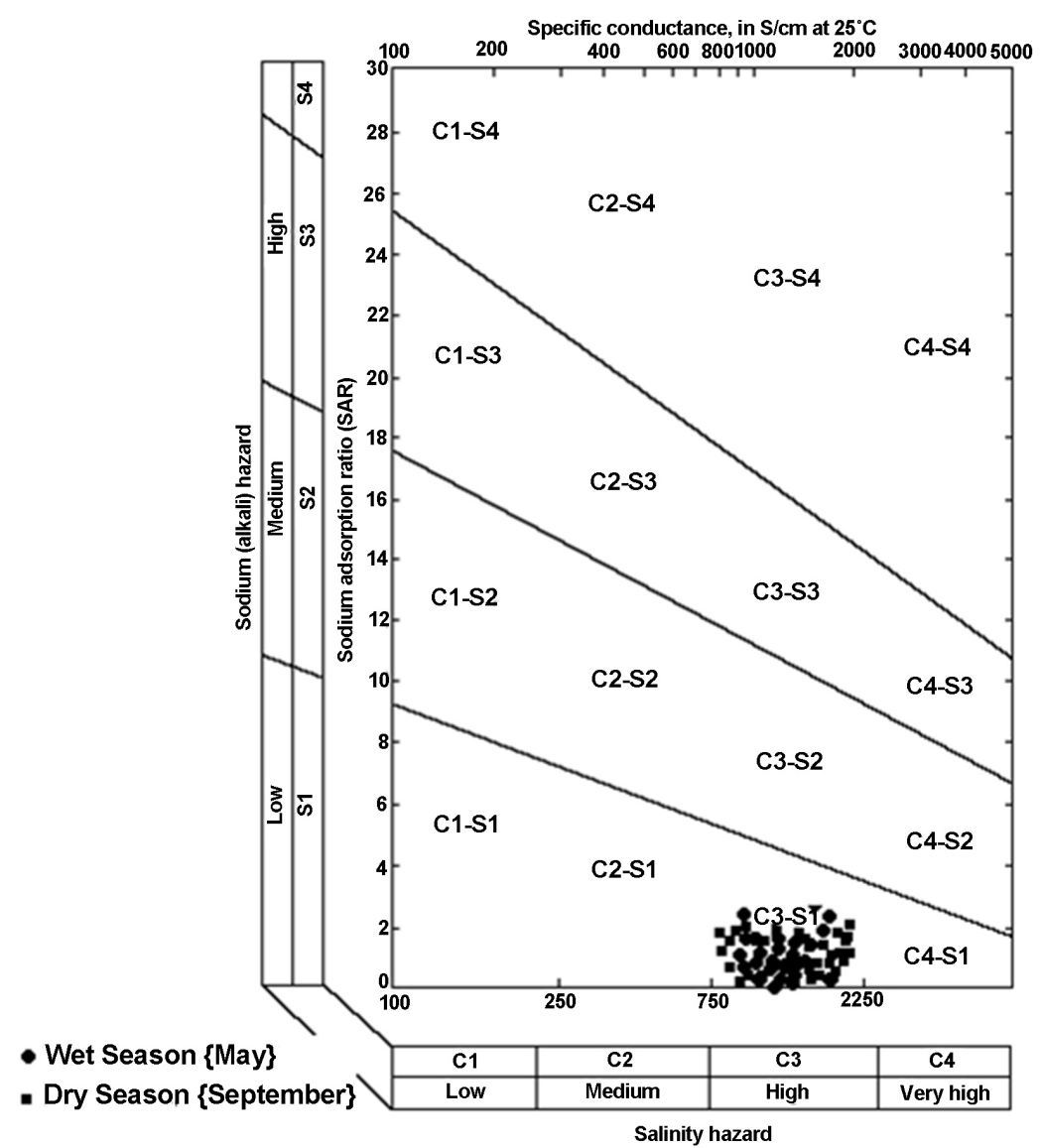

Figure 8. Classification of dam water for irrigation purposes.

soil to reduce its permeability. The sodium percentage $(\mathrm{Na} \%)$ is calculated using the formula given below:

$$
\mathrm{Na} \%=\{\mathrm{Na}+\mathrm{K} /(\mathrm{Ca}+\mathrm{Mg}+\mathrm{Na}+\mathrm{K})\} \times 100
$$


where all of the concentrations are expressed in meq/l.

The sodium percentage indicates that the water is good to permissible for irrigation (Table 7). All samples in the wet season are classified as good water for irrigation, while in dry season $69.4 \%$ of water samples are classified as good water, and others are classified as permissible water for irrigation (Table 7). When the concentration of sodium is high value in irrigation water, sodium ions tends to be adsorbed by clay minerals, displacing $\mathrm{Mg}^{2+}$ and $\mathrm{Ca}^{2+}$ ions. This exchange process of sodium in water calcium and magnesium in soil reduced the permeability and eventually results in soil with weak internal drainage [18] [28].

In addition to the sodium adsorption ratio (SAR) and sodium percentage $(\% \mathrm{Na})$, the residual sodium carbonate (RSC) represents the excess sum of carbonate and bicarbonate over the sum of calcium and magnesium also influences the unsuitability of water resources for irrigation. The residual sodium carbonate (RSC) is calculated by the following equation:

$$
\mathrm{RSC}=\left(\mathrm{HCO}_{3}^{-}+\mathrm{CO}_{3}^{2-}\right)-\left(\mathrm{Ca}^{2+}+\mathrm{Mg}^{2+}\right)
$$

where the concentration of ions is expressed in meq/l.

The classification of irrigation water in the Tannur dam according to the residue sodium carbonate (RSC) values is shows in Table 8 . The first category has (RSC) $<1.25$ epm (good quality). The second category has ranged from 1.25 to 2.5 epm (doubtful), while the third category has more than 2.5 epm (unsuitable). Table 8 shows the samples in two time periods and their relevant class. Results shown in this table indicate that the water of Tannur dam is mostly of good quality.

The permeability index (PI) values also indicate that the water of Tannur dam is suitable for irrigation. The permeability index is shown in the following equation:

$$
\mathrm{PI}=\left(\mathrm{Na}^{+}+\sqrt{ } \mathrm{HCO}_{3}^{-}\right) \times 100 /\left(\mathrm{Ca}^{2+}+\mathrm{Mg}^{2+}+\mathrm{Na}^{+}\right)
$$

where all values of ions are expressed in meq/l.

The permeability index (PI) in water from Tannur dam ranged from $34 \%$ to $43 \%$ during May 2015. On the other hand, in dry season the PI varied from $45 \%$ to $60 \%$ during September 2015, which found under class-1 of Doneen's chart [40].

Table 7. Suitability of dam water for irrigation based on the $\% \mathrm{Na}$.

\begin{tabular}{cccccc}
\hline & & \multicolumn{2}{c}{ Wet season } & \multicolumn{2}{c}{ Dry season } \\
\hline$\% \mathrm{Na}$ & Water class & No. of samples & Samples $\%$ & No. of samples & Samples \% \\
\hline$<20$ & Excellent & - & - & - & - \\
$20-40$ & Good & 36 & 100 & 28 & 77.8 \\
$40-60$ & Permissible & - & - & 8 & 22.2 \\
$60-80$ & Doubtful & - & - & - & - \\
$>80$ & Unsuitable & - & - & - & - \\
\hline
\end{tabular}


Table 8. Water quality based on residual sodium carbonate $\left(\mathrm{Na}_{2} \mathrm{CO}_{3}\right)$.

\begin{tabular}{cccccc}
\hline & & \multicolumn{2}{c}{ Wet season } & \multicolumn{2}{c}{ Dry season } \\
\hline RSC (meq/l) & Remark on quality & No. of samples & Samples \% & No. of samples & Samples \% \\
\hline$<1.25$ & Good & 30 & 83.3 & 22 & 61.1 \\
$1.25-2.5$ & Doubtful & 6 & 16.7 & 14 & 38.9 \\
$>2.5$ & Unsuitable & - & - & - & - \\
\hline
\end{tabular}

\section{Conclusion}

In this study water samples of the Tannur dam were collected to evaluate the hydrochemical characteristics of water and suitability for domestic, irrigation and industrial purposes. Physical and chemical parameters of water were determined; such as temperature, $\mathrm{pH}$, conductivity, dissolved oxygen, total dissolved solid (TDS), total hardness(TH), cations $\left(\mathrm{Ca}^{2+}, \mathrm{Mg}^{2+}, \mathrm{Na}^{+}\right.$and $\left.\mathrm{K}^{+}\right)$and anions $\left(\mathrm{HCO}_{3}^{-}, \mathrm{Cl}^{-}, \mathrm{NO}_{3}^{-}\right.$and $\mathrm{SO}_{4}^{2-}$ ). Results show that water samples in the study area were hard to very hard in nature. The PHREEQC hydro-geochemical modeling was used to obtain the saturation indices of specific mineral phases, which might be related to interaction with water and aquifer, and to identify the chemical species of the dissolved ions. The thermodynamic calculations indicate that most of the water samples are undersaturated with respect to halite, gypsum and anhydrate, and are saturated and oversaturated with respect to calcite and dolomite. The hydrogeochemistry behavior is rather complicated and is affected by anthropogenic and natural sources. The abundance of the major ions in water samples is in the following order: $\mathrm{HCO}_{3}^{-}>\mathrm{Ca}^{2+}>\mathrm{Cl}^{-}>\mathrm{NO}_{3}^{-}>\mathrm{SO}_{4}^{2-}>$ $\mathrm{Na}^{+}>\mathrm{Mg}^{2+}>\mathrm{K}^{+}$. Water samples of the Tannur dam are generally very hard, high to very high saline and medium alkaline in nature. High total hardness (TH) and total dissolved solids (TDS) in some samples identify the permissible for domestic and irrigation purposes. According to the residual sodium carbonate, sodium adsorption ratio, and sodium percentage values, the dam water can be used for irrigation purposes. The inorganic constituents of the water were influenced by lithology, anthropogenic activities. Some water samples are highly affected by human activities and agricultural activities around the dam. The integrated management of water samples for domestic, irrigation and industrial purposes to solve the water scarcity is not only in the studied area but also in other watershed. This study recommends continuous monitoring of the Tannur dam water, and protection of the dam from pollutants that originate from human activities and chemical fertilizers used in agricultural activities beside the dam.

\section{Conflicts of Interest}

The authors declare no conflicts of interest regarding the publication of this paper.

\section{References}

[1] Howari, F.H., Abu-Rukah, Y. and Shinaq, R. (2005) Hydrochemical Analysis and 
Evaluation of Groundwater Resources of North Jordan. Water Resources, 32, 555-564. https://doi.org/10.1007/s11268-005-0071-7

[2] El Naqa, A. and Al Kuisi, M. (2004) Hydrogeochemical Modeling of Water Seepages through Tannur Dam, Southern Jordan. Environmental Geology, 45, 1087-1100. https://doi.org/10.1007/s00254-004-0967-6

[3] Salameh, E. and Bannayan, H. (1993) Water Resources of Jordan Present Status and Future Potentials. Royal Society for the Conservation of Nature, Amman.

[4] Salameh, E. (1996) Water Quality Degradation in Jordan. Royal Society for the Conservation of Nature, Amman.

[5] Al-Khashman, O.A., Abu-Hamatteh, Z., Abu-Nameh, A., Abbassi, B. and Al-Whoosh, K. (2010) Environmental Assessment of Spring Water in Tafila District, Southern Jordan: Quality and Chemistry. Water International, 35, 78-93. https://doi.org/10.1080/02508060903504105

[6] Al-Tabbal, J.A. and Al-Zboon, K.K. (2012) Suitability Assessment of Groundwater for Irrigation and Drinking Purpose in the Northern Region of Jordan. Journal of Environmental Science and Technology, 5, 274-290. https://doi.org/10.3923/jest.2012.274.290

[7] Al-Khashman, O.A. and Jaradat, A.G. (2014) Assessment of Groundwater Quality and Its Suitability for Drinking and Agricultural Uses in Arid Environment. Stochastic Environmental Research and Risk Assessment, 28, 743-753. https://doi.org/10.1007/s00477-013-0787-x

[8] Al-Khashman, O.A., Alnawafleh, H.M., Abu Jrai, A.M. and Al-Muhtaseb, A.H. (2017) Monitoring and Assessing of Spring Water Quality in Southwestern Basin of Jordan. Open Journal of Modern Hydrology, 7, 331-349. https://doi.org/10.4236/ojmh.2017.74019

[9] Department of Meteorology (2004) Internal Report. Amman.

[10] Bender, F. (1974) Geology of Jordan. Gebrüder Borntraeger, Berlin, 230 p.

[11] Macdonald, M. (1965) Hydrogeological Survey of the Madaba-Ma'an Area, Vol. 2. The Water Authority of Jordan (Internal Report), Amman, 30 p.

[12] Tarawneh, B. (1988) The Geology of Al-Tafila. Natural Resources Authority, Bulletin 12, Amman.

[13] Bandel, K. and Salameh, E. (2013) Geologic Development of Jordan-Evolution of Its Rocks and Life. The University of Jordan Press, Amman, 276 p.

[14] Powell, J. and Moh'd, B. (2011) Evolution of Cretaceous to Eocene Alluvial and Carbonate Platform Sequences in Central and South Jordan. GeoArabia, 16, 29-82.

[15] GTZ (1977) National Water Master Plan of Jordan. Vol. III \& IV. Groundwater Resources. Federal Institute for Geosciences and Natural Resources, Hanover, 55.

[16] Al-Khashman, O.A. (2007) Study of Water Quality of Springs in Petra Region, Jordan: A Three-Year Follow-Up. Water Resources Management, 21, 1145-1163. https://doi.org/10.1007/s11269-006-9073-8

[17] WAJ (2001) Internal Files of the Groundwater Data in the Jordan Valley Area. Water Authority of Jordan, Amman.

[18] Japan International Cooperation Agency (JICA) (1995) The Study on Brackish Groundwater Desalination in Jordan. Yachiyo Engineering Co. Ltd., Tokyo, 318 p.

[19] Sahawneh, J., Swarieh, A. and Masarweh, R. (2000) Geology and Hydrogeology of the Northern Wadi Araba Basin. Natural Resources Authority, Internal Report, No. 11, Amman, $88 \mathrm{p}$.

[20] Al-Khashman, O.A. (2002) Environmental Status of the Area Extending between 
Wadi El-Hasa and Wadi Musa from the Railway to Wadi Araba. PhD Thesis, University of Jordan, Amman, 177 p.

[21] Humphreys, H., et al. (1995) The Study and Design of Tannur Dam. Draft Final Report, Vol. 1, Site Investigation, Internal Report, Jordan Valley Authority of Jordan, Amman.

[22] Virkutyte, J. and Sillanpaa, M. (2006) Chemical Evaluation of Potable Water in Eastern Qinghai Province, China: Human Health Aspects. Environmental International, 32, 80-86. https://doi.org/10.1016/j.envint.2005.05.022

[23] Momani, K.A. (2006) Chemical Assessment of Bottled Drinking Waters by IC, GC, and ICP-MS. Instrumentation Science \& Technology, 34, 587-605. https://doi.org/10.1080/10739140600811740

[24] Mouli, P., Mohan, S.V. and Reddy, S.J. (2005) Rainwater Chemistry at a Regional Representative Urban Site: Influence of Terrestrial Sources on Ionic Composition. Atmospheric Environment, 39, 999-1008. https://doi.org/10.1016/j.atmosenv.2004.10.036

[25] Zacheus, O.M. and Martikainen, P.J. (1997) Physicochemical Quality of Drinking and Hot Waters in Finnish Building Originated from Groundwater or Surface Water Plants. Science of the Total Environment, 204, 1-10. https://doi.org/10.1016/S0048-9697(97)00160-5

[26] Drever, J.I. (1997) The Geochemistry of Natural Waters, New York. Prentice Hall, Upper Saddle River.

[27] Todd, D. (1980) Groundwater. 2nd Edition, John Wiley and Sons, New York, 535.

[28] Saleh, A., Al-Ruwaih, F. and Shehata, M. (1999) Hydrogeochemical Processes Operating within the Main Aquifers of Kuwait. Journal of Arid Environment, 42, 195-209. https://doi.org/10.1006/jare.1999.0511

[29] Al-Khashman, O.A. (2008) Assessment of the Spring Water Quality in the Shoubak Area, Jordan. Environmentalist, 28, 203-215. https://doi.org/10.1007/s10669-007-9129-1

[30] Gulbahar, N. and Elhatip, H. (2005) Estimation of Environmental Impacts on the Water Quality of the Tahtahdam Watershed in Izmir, Turkey. Environmental Geology, 47, 725-728. https://doi.org/10.1007/s00254-004-1206-X

[31] Amanial, H.R. (2015) Assessment of Physicochemical Quality of Spring Water in Arbaminch, Ethiopia. Journal of Environmental Analytical Chemistry, 2, 157-159. https://doi.org/10.4172/2380-2391.1000157

[32] Subyani, A.M. (2005) Hydrochemical Identification and Salinity Problem of Groundwater in Wadi Yalamlam Basin Western Saudi Arabia. Journal of Arid Environments, 60, 53-66. https://doi.org/10.1016/j.jaridenv.2004.03.009

[33] Fetter, C.W. (1988) Applied Hydrogeology. 2nd Edition, Merrill Publishing Company, London, 592.

[34] Piper, A.M. (1944) A Graphic Procedure in the Geochemical Interpretation of Water Analysis. Eos, Transactions American Geophysical Union, 25, 914-928. https://doi.org/10.1029/TR025i006p00914

[35] Furtak, H. and Langguth, H.R. (1967) Zurhydrochemischen Kennzeichnung von Grundwässern und Grundwassertypenmittels Kennzahlen. International Association Hydrogeology, 7, 89-96.

[36] Sawyer, C.N. and McCarty, P.L. (1967) Chemistry and Sanitary Engineers. 2nd Edition, McGraw-Hill, New York.

[37] Baalousha, H. (2010) Assessment of a Groundwater Quality Monitoring Network 
Using Vulnerability Mapping and Geostatistics: A Case Study from Heretaunga Plains, New Zealand. Agricultural Water Management, 97, 240-246. https://doi.org/10.1016/j.agwat.2009.09.013

[38] Subramani, T., Elango, L. and Damodarasamy, S. (2005) Groundwater Quality and Its Suitability for Drinking and Agricultural Use in Chithar River Basin, Tamil Nadu, India. Environmental Geology, 47, 1099-1110. https://doi.org/10.1007/s00254-005-1243-0

[39] Richards, L.A. (1954) Diagnosis and Improvement of Saline Alkali Soils. US Department of Agriculture, Hand Book 60, Washington DC, 160. https://doi.org/10.1097/00010694-195408000-00012

[40] Domenico, P.A. and Schwartz, F.W. (1990) Physical and Chemical Hydrogeology. Wiley, New York, 410-420. 